\title{
GENERATIES, HERINNERING EN HISTORICITEIT
}

'Generatie' is een term die in de geschiedschrijving veelvul-

dig gebruikt wordt om tijdscontrasten te schetsen. Slechts

weinig historici staan stil bij wat generaties nu eigenlijk

zijn en wie dat wel doet moet leentjebuur spelen bij de

sociologie. In dit artikel worden enkele geschiedtheoretische

problemen met de sociologische generatietheorie van Karl

Mannheim besproken. Ook wordt een voorstel gedaan voor

een generatietheorie waarin de tijdservaring verdisconteerd

is, om zo de besproken problemen te ondervangen.'

Binnen de Nederlandse geschiedschrijving heeft de generatietheorie nooit vaste voet aan de grond gekregen. Hoewel historici veelvuldig het begrip 'generatie' hanteren om in hun geschiedverhaal temporele contrasten te schetsen, wordt slechts zelden gereflecteerd op de implicaties van het gebruik van de term 'generatie' - laat staan op de conceptuele achtergrond hiervan. Wanneer men wel teruggrijpt op de bestaande generatietheorie, gebeurt dit vaak oppervlakkig of wordt de theorie enkel ingezet als een legitimatie voor het eigen onderzoek. ${ }^{2}$ Wie wel de vraag stelt naar de conceptuele en theoretische achtergronden van het generatiebegrip komt steevast uit bij de sociologische generatietheorie.

Sinds 1928 geldt het essay 'Das Problem der Generationen' van Karl Mannheim als canoniek referentiepunt voor eenieder die zich met generaties bezighoudt. ${ }^{3}$ De socioloog Mannheim brengt in dit essay het vol-

\author{
Robbert-Jan Adriaansen
}

strekt versnipperde generatieonderzoek van de voorgaande eeuw in kaart en presenteert zijn eigen - door het historisch materialisme geïnspireerde - generatietheorie als synthese van eerdere positivistische en historistische aanzetten tot theorievorming. De introductie van Mannheims generatietheorie in Nederland is voornamelijk de verdienste geweest van de uit nazi-Duitsland uitgeweken filosoof Helmut Plessner, wiens voordracht over 'Het probleem der generaties' in 1949 gepubliceerd werd in het Sociologisch Jaarboek. ${ }^{4}$ Sprekend op verzoek van de Nederlandse Sociologische Vereniging op een symposium over de mentaliteit van de naoorlogse jeugd, koppelde Plessner de generatietheorie terug aan het idee van de emancipatie van de jeugd, zoals dat in de Duitse jeugdbeweging aan het begin van de twintigste eeuw gestalte had gekregen. Hoewel Plessner met zijn voordracht vooral een sociologisch publiek aansprak, zou onder de Nederlandse historici Ger Harmsen de thematiek en theorie oppakken voor zijn proefschrift over de Nederlandse jeugdbeweging. ${ }^{5}$

De meest recente opleving van de generatiediscussie in de Nederlandse geschiedschrijving was in de jaren negentig, toen de Utrechtse historicus Hans Righart zijn cultuurhistorisch onderzoek naar de 'sixties' publiceerde onder de titel De eindeloze jaren

1 Deze bijdrage is deels gebaseerd op: Robbert-Jan Adriaansen, Tussen ervaring en herinnering. Generaties en geschiedschrijving (Rotterdam 2006, master thesis Erasmus Universiteit).

2 Zie hierover: Jürgen Zinnecker, '“Das Problem der Generationen”. Überlegungen zu Karl Mannheims kanonischem Text', in: Jürgen Reulecke, Generationalität und Lebensgeschichte im 20. Jahrhundert (München 2003) 33-58; 33.

3 Karl Mannheim, 'Das Problem der Generationen', in: idem, Wissenssoziologie (Berlijn 1964) 509-565.

4 Helmuth Plessner, 'Het probleem der generaties', Sociologisch Jaarboek III (1949) 3-24.

5 Ger Harmsen, Blauwe en rode jeugd, ontstaan, ontwikkeling en teruggang van de Nederlandse jeugdbeweging tussen 1853 en 1940 (Assen 1961). Zie ook: Ger Harmsen, Nieuwe inleiding tot de geschiedenis (Nijmegen 1998) 142-144. 
zestig. ${ }^{6}$ In dit boek past Righart Mannheims generatietheorie nauwgezet toe en constateert hij dat aan het heftige generatieconflict uit de jaren zestig niet enkel het problematisch jong-zijn van de 'protestgeneratie' ten grondslag lag, maar dat ook de oudergeneratie te kampen had met een identiteitscrisis die katalyserend werkte. Deze laatste waarneming brengt Righart tot de conclusie dat de welvaartsstijging van de jaren zestig heeft geleid tot een 'dubbele generatiecrisis'.

Righarts toepassing van Mannheims generatietheorie had ongetwijfeld minder stof doen opwaaien als niet in hetzelfde jaar een andere studie over de 'sixties' verschenen was, waarin zonder gebruikmaking van het generatieconcept geheel andere conclusies getrokken werden. In Nieuw Babylon in aanbouw benadrukt James Kennedy juist dat de jaren zestig in Nederland verhoudingsgewijs rustig zijn verlopen. ${ }^{?}$ Het was voornamelijk aan de inschikkelijkheid en het aanpassingsvermogen van de - toch verzuilde en conservatieve - bestuurlijke elite te danken dat Nederland zonder al te veel kleerscheuren het decennium van versnelde modernisering door is gekomen. Volgens Kennedy was van een generatieconflict dan ook geen sprake.

$\mathrm{Na}$ de publicatie van beide boeken in 1995 ontspon zich een kort, maar heftig debat over de vraag welke aanpak nu het meest representatieve beeld van de jaren zestig neerzette. Righart verweet Kennedy teveel nadruk te leggen op de historische continuïteit door het breukkarakter van de jaren zestig te relativeren en de aanpassingsgezindheid van de politieke elites te plaatsen in een eeuwenoude traditie van nuchter polderen. ${ }^{8}$ Kennedy daarentegen benadrukte dat zijn preoccupatie met de politieke elites niet zozeer was ingegeven door het idee dat zij de dragers waren

Hans Righart, De eindeloze jaren zestig. Geschiedenis van een generatie. conflict (Amsterdam 1995).

7 James Kennedy, Nieuw Babylon in aanbouw. Nederland in de jaren zestig (Amsterdam 1995).

8 In zijn postuum gepubliceerde De wereldwijde jaren zestig meent Righart zelfs van een Nederlandse variant van de 'Whig interpretation of history' te moeten spreken. Zie: Hans Righart, De wereldwijde jaren zestig: GrootBritannië, Nederland, de Verenigde Staten (Hilversum 2004) 98.

9 James Kennedy. 'New Babylon and the Politics of Modernity', Sociologische Gids 44 (1997) 361-374; 363.

10 Righart, De eindeloze jaren zestig, 226

11 Generationaliteit verwijst naar de identificatie met ervaren of toegeschreven eigenschappen van een generatie. Zie: Jurgen Reulecke, 'Einführung: Lebensgeschichten des 20. Jahrhunderts im "Cenerationencontainer"?', in idem: ed., Generationalität und Lebensgeschichte im 20. Jahrhundert (München 2003) vii-xvi; viii. van het Nederlandse moderniseringsproces, maar juist door de overtuiging dat het de elites waren die het moderniteitsdiscours domineerden. ${ }^{9}$ Hiermee suggereerde Kennedy dat Righart te weinig aandacht had besteed aan de discursieve constructie van de werkelijkheid.

Het lijkt er inderdaad op dat Righart op zijn eigen, meeslepende, wijze de mythes van de jaren zestig eerder heeft bekrachtigd dan ontmaskerd. Een bekrachtiging die zich wellicht het sterkst uit in de titel van zijn boek, want 'voor zover "de jaren zestig" naast een ingewikkelde verstrengeling van modernisering en generatiestrijd ook een taaie mythe zijn', is voor Righart het einde van de jaren zestig onvindbaar. ${ }^{10}$ Hier komen de tekortkomingen van het generatieconcept pas echt aan het licht. Aangezien Mannheim de generatie interpreteert als een sociale realiteit en als zodanig als constitutief voor de historische dynamiek, kunnen deze 'mythes' slechts opgevat worden als uitingen van generationaliteit. ${ }^{11}$ Vanuit dit perspectief is het een open deur dat het einde van de jaren zestig nog niet in zicht is op het moment dat de protestgeneratie op middelbare leeftijd is.

De vraagt doemt dan op wat de relatie tussen generationaliteit en narratio nu werkelijk is en hoe generaties zich in en tot het verleden verhouden. Wordt het niet tijd enig achterstallig onderhoud te plegen aan een ruim tachtig jaar oude theorie die door veel historici nog minder kritisch dan door Righart wordt toegepast in de geschiedschrijving? Om deze vragen te beantwoorden zal ik beginnen met een kritische bespreking van het nut en nadeel van Mannheims sociologische generatietheorie voor de geschiedschrijving. $\mathrm{Na}$ deze inhoudelijke analyse zal ik een mogelijkheid bespreken om de voornoemde impasse tussen generatie en geschiedenis te doorbreken, namelijk door de generatie te interpreteren als een metahistorische categorie, in plaats van een methodisch model. Deze benadering vraagt om een herinterpretatie van de kern van Mannheims these, van de tijdservaring in de adolescentie en jongvolwassenheid die aan de generatievorming ten grondslag ligt.

\section{Het probleem der generaties}

Het generatiebegrip dat Mannheim hanteert is uitdrukkelijk een modern generatiebegrip. 


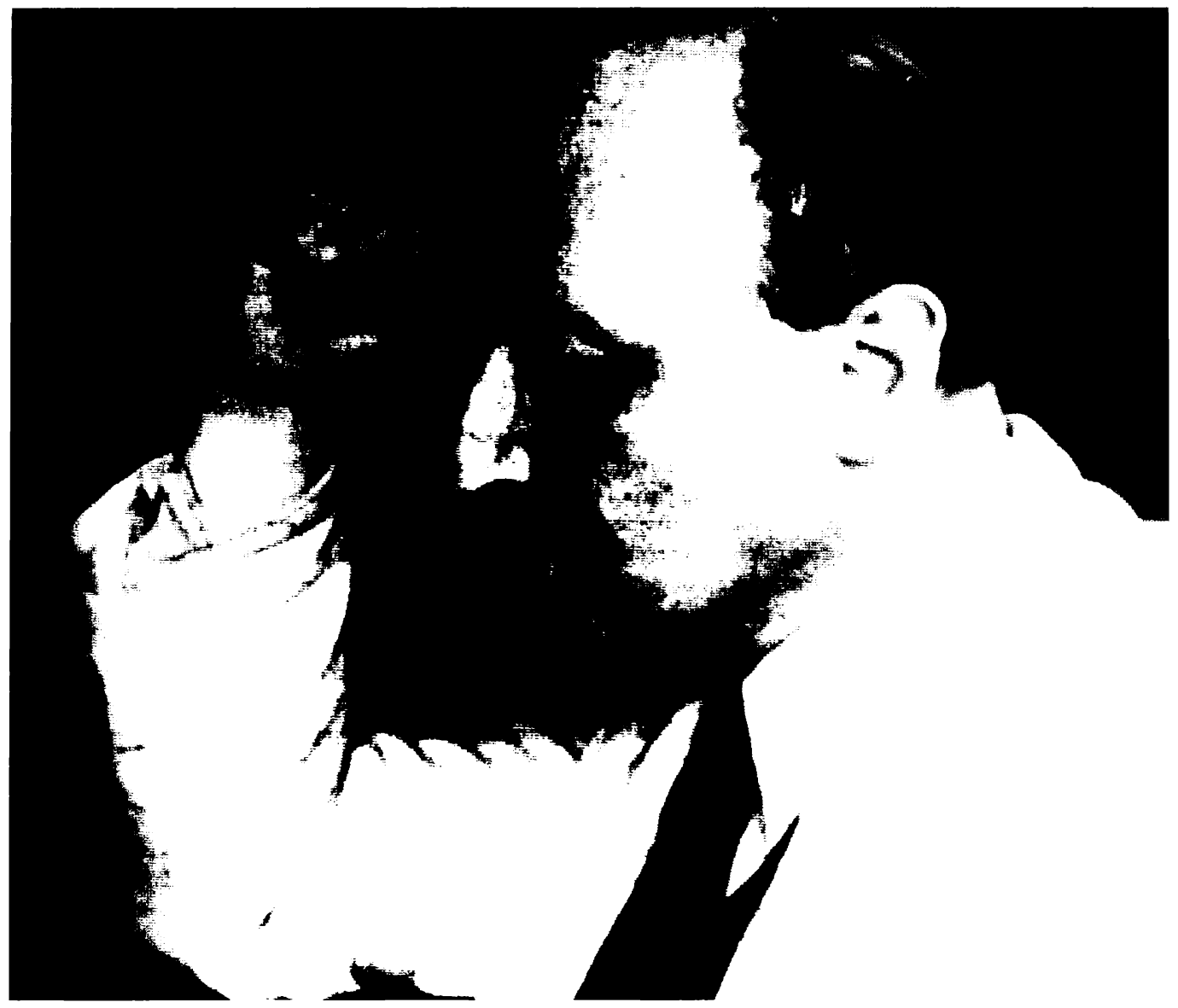

Karl Mannheim.

Bron: Robert Wohl, The Generation of 1914 (Harvard University Press 1979)

Mannheim gaat uit van sociale generaties die bestaan uit groepen mensen die in hetzelfde historisch tijdsgewricht geboren zijn en onder invloed van een gelijksoortige socialisatie en dezelfde levenservaringen een gelijkvormige levenshouding aannemen. Dit type generatieopvatting staat in schril contrast met de voormoderne conceptualisering, waarin generaties - zowel in de familiale als in de sociale connotatie - geïnterpreteerd werden als ketens in een genealogische reeks waarin afstamming en continuiteit centraal staan. ${ }^{12}$ Uit deze voormoderne generatiebetekenis klinkt een cyclisch tijdsbesef, waarvan we de meest treffende bewoording reeds bij Homerus tegenkomen, wanneer hij genera- tiewisseling vergelijkt met de afwisseling van de seizoenen. ${ }^{13}$

De intrede van de moderniteit met de Franse Revolutie als symbolisch omslagpunt bracht een betekenisverschuiving voort, waarbij het generatiebegrip los kwam te staan van de natuurlijke cyclus van opkomst, bloei en verval. De generatie werd nu juist

12 Ulrike Jureit, Generationenforschung (Göttingen 2006) 31. Zie ook: Siegried Weigel, Genea-Logik. Generation. Iradition und Evolution zwi schen Kultur- und Naturwisserischaften (Paderborn 2006)

13 'Als het geslacht van de bladeren gaat het de mensengeslachten: over de aarde waaien zij weg op de wind, maar in' 't voorjaar doet het uitbot:cend bos de nieuwe bladeren ontluiken. Zo bloet het ene mensengeslacht waar het andere afsterft', Homerus. Ilias VI:145-149. geciteerd in: Jan van der Dussen, Geschiedenis en beschaving. Kritische opstellen over verleden, heden en toekomst (Hilversum 2005) 2:5. 
in verband gebracht met menselijk handelen en met sociale verandering. Pierre Nora karakteriseert dit moderne generatiebegrip treffend als de 'dochter van de democratie en de versnelling van de geschiedenis.'. ${ }^{14} \mathrm{Als}$ vanzelfsprekend verliep de transitie van het voormoderne naar het moderne generatiebegrip niet abrupt, maar zijn er in de hele moderne geschiedenis aanzetten te vinden waarin men een ritmisch-biologische generatieopvatting probeert te rijmen met het moderne vooruitgangsdenken.

In navolging van de vader van de moderne sociologie, Auguste Comte, beschouwden positivistische generatietheoretici uit de late negentiende en vroege twintigste eeuw generaties als de motor achter de historische vooruitgang, terwijl ze voor de praktische uitwerking van hun generatietheorie terugvielen op de ritmische afwisseling van generaties in de samenleving. Generaties werden geanalyseerd als geboortecohorten die in de 'werkzame' levensfase het maatschappelijk leven domineren en controleren. Omdat demografische factoren, zoals de gemiddelde levensverwachting en de gemiddelde leeftijd waarop men een eerste kind krijgt, berekenbaar zijn, kan het interval van generatieafwisseling dienen als uitgangspunt voor de analyse van maatschappelijke verandering. ${ }^{15}$

Het was Wilhelm Dilthey die met een op het historisme gestoelde generatietheorie een streep zette door het cyclisch-biologische generatiedenken en de nadruk verlegde van de kwantitatieve naar de kwalitatieve kenmerken van de generatie. Dilthey onderzocht dat wat de positivisten al impliciet veronderstelden: het idee dat generaties intrinsiek van elkaar verschillen. Het is het gelijktijdig ervaren van dezelfde gebeurtenissen en ontwikkelingen in de jeugd dat volgens Dilthey ten grondslag ligt aan de vorming van een specifieke generatie. ${ }^{16}$ Wanneer onder invloed

14 Pierre Nora, 'Generations', in: idem ed., Realms of Memory: Rethinking the French Past, Vol. I (New York 1996) 498-531; 509.

15 Auguste Comte, Cours de philosophie positive IV (Parijs 1849)635-641. Zie ook: Robert Wohl, The Generation of 1914 (Cambridge, Mass. 1979) 18-20.

16 Wilhelm Dilthey, 'Über das Studium der Geschichte der Wissenschaften vom Menschen, der Gesellschaft und dem Staat', in: idem, Gesammelte Schriften V( Göttingen 1990) 36-41; 37.

17 Wilhelm Dilthey, 'Novalis', in: idem, Das Erlebnis und die Dichtung Gesammelte Schriften XXVI. Band (Göttingen 2005) 173-223; 175.

18 John Neubauer, The Fin-de-Siècle Culture of Adolescence (New Haven 1992).

19 Zie: Erik H. Erikson, Identity: Youth and Crisis (New York 1968).

20 Zie hiervoor: Wohl, The Generation of 1914. van deze ervaringen onder leeftijdsgenoten een gedeelde 'geistige Kultur' ontstaat, kan men van een generatie spreken. ${ }^{17}$ Een dergelijke 'geistige Kultur' lag volgens Dilthey ten grondslag aan de Duitse Romantiek.

Het is belangrijk te benadrukken dat Dilthey hier voor het eerst het generatieconcept expliciet koppelt aan de jeugd. Bij Comte en andere positivistisch ingestelde generatietheoretici lag de nadruk vooral op de volwassenheid, aangezien dit de levensfase is waarin men effectief invloed uit kan oefenen op en in de maatschappij. In de volwassenheid bezet men immers de sociale posities die het mogelijk maken om woorden in daden om te zetten. Dilthey echter schreef in wat later wel de 'fin-de-siècle cultuur van de adolescentie' genoemd is - een sociaal-intellectuele omgeving die in toenemende mate de jeugd als een aparte levensfase tussen kind- en volwassenheid in ging thematiseren. ${ }^{18}$ Toenemende scholingsmogelijkheden, en later -plichten, plaatsen leeftijdsgenoten gezamenlijk in een omgeving waarin zij relatief verantwoordingsvrij een verlengde kindertijd door konden maken. In de psychologie werd de jeugd als adolescentie getypeerd als een autonome levensfase van - zoals Erik Erikson het later uit zou drukken - identiteitscrisis. ${ }^{19}$ Bovendien kreeg deze levensfase in Duitsland spoedig praktische invulling door het ontstaan van de vrije Duitse jeugdbeweging, waarmee de 'jeugdcultus' voor het eerst sociaal gestalte kreeg. $\mathrm{Na}$ de Eerste Wereldoorlog vierde het 'generationalisme' hoogtij, toen de gedesillusioneerde 'frontgeneratie' die haar bloed had vergoten in de titanenstrijd van het oude Europa generatieretoriek in de mond nam om de komst van een nieuw Europa te verkondigen. ${ }^{20}$ In deze context schreef Karl Mannheim aan het einde van de jaren twintig zijn generatietheorie.

Hoewel in de generatieretoriek van de jaren twintig sterk de nadruk werd gelegd op de kwalitatieve kenmerken van een generatie, verloor Mannheim het biologische element niet uit het oog. Hij zag zijn theorie als een noodzakelijke synthese van de positivistische en de historistische benaderingswijzen uit de negentiende eeuw. De demografische aspecten vormden voor Mannheim een noodzakelijke, maar geen voldoende voorwaarden bij de totstandkoming van een generatie. Een zuiver positivistische werkwijze, waarbij de 
demografie wel als voldoende voorwaarde voor generatievorming geïnterpreteerd werd, zou volgens Mannheim de geschiedenis reduceren tot een 'chronologische tabel'. ${ }^{21}$ Aan de andere kant legde de historistische traditie volgens hem te veel nadruk op de rol van de individuele ervaring en te weinig op het belang van de sociale context bij de vorming van een generatie. ${ }^{22}$

Om uit deze theoretische impasse te komen kwam Mannheim met een analysemodel aan de hand waarvan de totstandkoming van een generatie onderzocht kan worden. Bij de analyse van generaties zijn drie 'lagen' te onderscheiden: de generatiepositie (Generationslagerung), de generatiesamenhang (Generationszusammenhang) en de generatie-eenheid (Generationseinheit). Onder de generatiepositie vallen in grote lijnen de demografische elementen die in de positivistische benadering domineerden. Analoog aan Karl Marx' begrip 'klassenpositie' (Klassenlage), dat refereert aan de feitelijke voorwaarden (het in bezit hebben van productiemiddelen of niet) die de positionering van een individu in een bepaalde klasse bepalen, omvat de generatiepositie de (demografische) voorwaarden die een individu in een bepaalde 'objectieve' generatie plaatsen. Zoals de klassenpositie de 'Klasse an sich' bepaalt, bepaalt de generatiepositie de 'Generation an sich'. De generatiepositie behelst enkel de voorwaarden - het in dezelfde cultureel-historische gemeenschap vrijwel gelijktijdig geboren worden - voor het ontstaan van een generatie, daar een generatie an sich zich (nog) niet bewust is van de eigen generatiepositie.

Dit bewustzijn staat centraal in de tweede 'analyselaag': de generatiesamenhang. Van generatiesamenhang is sprake wanneer men zich wel bewust wordt van de eigen generationaliteit en ook overeenkomstig gaat handelen. Deze samenhang ontstaat onder invloed van de collectieve ervaring van (historische) gebeurtenissen en veranderingen in de zogenaamde 'formatieve periode' van het leven: de periode tussen ruwweg het vijftiende en vijfentwintigste levensjaar waarin indrukken en ervaringen een wereldbeeld scheppen en waar identiteitsvorming plaatsvindt. ${ }^{23}$ Wanneer leeftijdsgenoten in hun formatieve periode dezelfde ervaringen ondergaan, ontwikkelen zij 'een specifieke wijze van beleven en den- ken' en hieruit 'een specifieke wijze van ingrijpen in het historisch proces'. ${ }^{24}$ Dit ingrijpen in het historisch proces gebeurt aan de hand van het besef te delen in een gezamenlijk lot (Schicksal). Samen met Diltheys these van de formatieve ervaring vormt deze (van Martin Heidegger geleende notie) Mannheims generatiesamenhang.

Een generatiesamenhang kan zich sociaal-politiek organiseren in zogenaamde generatie-eenheden. Kan, want net zo min als er uit een generatiepositie een generatiesamenhang hoeft te ontstaan, hoeft de generatieeenheid niet per definitie te volgen uit de generatiesamenhang. Als derde 'analyselaag' binnen Mannheims generatietheorie zijn generatie-eenheden de concrete politiek-culturele groepen die de met de generatiesamenhang ontstane 'Grundintentionen' van een generatie omzetten in praktisch handelen. Mannheim zag in dit kader voornamelijk de Duitse jeugdbeweging als voorbeeld van een generatie-eenheid.

Het 'gezamenlijk perspectief' van waaruit de generatie handelt noemde Mannheim de 'generatie-entelechie' - een begrip dat hij overnam van de kunsthistoricus Wilhelm Pinder. In zijn analyse van de Europese kunstgeschiedenis herleidde Pinder de opvolging van verschillende kunststromen tot de afwisseling van (kunstenaars-) generaties. De stijl die zij ontwikkelden hing samen met de zogenaamde 'entelechie', waaronder Pinder het innerlijke doel' van een generatie verstond. Dit doel valt moeilijk te grijpen en is ingeboren, in plaats van onder invloed van ervaringen ontstaan. ${ }^{25}$ Overigens is de generatie-entelechie niet de enig bestaande entelechie; ook andere historische eenheden, zoals naties, families en individuen kennen een ingeboren doeloriëntatie.

Hoewel in Pinders generatie-entelechie een zekere predestinatiegedachte zit, is in

21 Mannheim, 'Das Problem der Generationen', 512.

22 Mannheim chargeert hier de historistische benadering; het is zeker zo dat Dilthey in zijn filosofie de innerlijke ervaring of Erlebnis centraal stelt, maar hij is in zijn uitwerking van het generatiebegrip zeer uitgesproken over de invloed van sociale context (bijvoorbeeld opvoeding) op de innerlijke ervaring.

23 De formatieve periode komt overeen met de adolescentie. Mannheim neemt in navolging van de pedagoog Eduard Spranger het zeventiende levensjaar als aanvangspunt hiervan. Vgl. Eduard Spranger, Psychologie des Jugendalters (Heidelberg 1979) 44-56.

24 Mannheim, 'Das Problem der Generationen', 528.

25 Wilhelm Pinder, Das Problem der Generation in der Kunstgeschichte Europas (Berlijn 1926) 148. 
Mannheims generatietheorie de entelechie teruggekoppeld aan de formatieve ervaring. De 'Generationsentelechie' is voor Mannheim niet 'ingeboren', maar ontstaat wanneer zich vanuit een generatiepositie, onder invloed van - uit historische verandering ontstane - collectieve ervaringen, daadwerkelijk een generatie vormt. Op dat moment schept een generatie een nieuwe entelechie, daar waar bestaande entelechieën (nationale, confessionele, ideologische) niet langer beantwoorden aan de nieuwe maatschappelijke status quo. De generatie-entelechie is dan het raamwerk van opvattingen, inzichten en orientaties dat het collectief en individueel handelen van (leden van) een generatie bepaalt.

Overigens kunnen er volgens Mannheim verschillende entelechieën binnen één generatie bestaan. Of beter gezegd: binnen verschillende, gelijktijdig naast elkaar bestaande, niet-generationele (bijvoorbeeld politiek-ideologische), entelechieën kunnen leden van eenzelfde biologische generatie in reactie op dezelfde formatieve ervaringen verschillende entelechieën ontwikkelen. ${ }^{26}$ Zo ontstonden er in het Duitsland van 1919 in reactie op de formatieve ervaring van de Eerste Wereldoorlog zowel binnen de rechtsnationale als socialistische entelechie geradicaliseerde generatie-entelechieën (NSDAP en KPD).

Omdat de generatie-entelechie doelgeorienteerd is, dient de generatie-entelechie door de leden van de generatie omgezet te worden in praktisch handelen. Nieuwe generaties en generatie-entelechieën ontstaan bij gratie van de 'veroudering' van de denkbeelden van de voorgaande generaties die het maatschappelijk toneel beheersten. Dit impliceert dat zowel het generationeel handelen als de generatie-entelechie onveranderlijk blijven in de rest van de levensloop. Was dit niet het geval, dan zouden denkbeelden nooit 'verouderen' en zouden er nooit generaties opstaan om hun eigen ervaringen met metagenerationele entelechieën in het reine te brengen.

Het feit dat de generatietheorie gebaseerd is op de notie van een aan historische verandering onderhevige wereld maakt haar tot een geschiedwetenschappelijk uiterst re- levante categorie. De vraag is echter of de kennissociologische aanpak van Mannheim ook zonder meer in de geschiedwetenschap toepasbaar is.

\section{Het probleem van de generatietheorie}

Mannheims theorie gaat verder dan het beantwoorden van de vraag hoe generaties ontstaan. De generatietheorie gaat er immers van uit dat generaties niet enkel voortkomen uit historische ontwikkelingen, maar dat ze ook zelf het historisch proces beïnvloeden. Op deze manier laat de theorie niet alleen de geschiedenis begrijpen, maar ook verklaren. Wanneer we echter deze sociologische generatietheorie inzetten als historisch verklaringsmodel, doen zich theoretische en praktische problemen voor die in de geschiedwetenschappelijke toepassing vaak over het hoofd worden gezien.

Ik wil hier enkele problemen bespreken die overwegend voortvloeien uit het historisch-materialistische denkkader dat aan Mannheim's generatietheorie ten grondslag ligt. Overigens wil ik hiermee niet betogen dat alle praktische en theoretische problemen met de generatietheorie hiertoe te herleiden zijn, maar wil ik enkel de aandacht vestigen op elementen uit de generatietheorie waarvan de consequenties tot nog toe niet grondig doordacht zijn.

Om te beginnen dient vermeld te worden dat Mannheims interpretatie van het historisch-materialistische gedachtegoed op een belangrijk punt afweek van dat van Karl Marx en van zijn eigen leermeester Georg Lukács. Mannheim was er namelijk van overtuigd dat het verkeerd was het historisch materialisme enkel in termen van klassen te denken. In plaats hiervan betoogt hij dat er kennis is (en dat er daarmee ook bewustzijnsvormen zijn) die los van de economische onderbouw tot stand kan komen. Naast sociale klassen gelden levenssferen, sekten, beroepsgroepen, scholen en vooral ook generaties als sociale omgevingen waarin kennisvormen kunnen ontstaan. ${ }^{27}$ Natuurlijk staan niet al deze groepen op gelijke hoogte, maar generaties nemen wel een bijzondere positie in, daar zij door de generatiewisseling en concurrentie de 'geistige Dialektik' van een samenleving bepalen. ${ }^{28}$

Hoewel de these dat generaties een cen-
7 Karl Mannheim, Ideologie und Utopie (Frankfurt am Main 1995) 237. 
trale rol spelen in de sociale constructie van kennis bijzonder plausibel klinkt, heeft de wijze waarop Mannheim haar analoog aan Marx' klassenconcept theoretiseert enkele belangrijke consequenties. ${ }^{29} \mathrm{Om}$ te beginnen wil ik stilstaan bij de koppeling die Marx maakt tussen 'zijn' en 'bewustzijn'. Vanuit zijn materialisme ziet Marx bewustzijn niet als een idealistisch gegeven, maar simpelweg als het praktische bewuste zijn van individuen en groepen in de wereld, waarmee hij voornamelijk doelde op het bewustzijn van de eigen klassenpositie. Georg Lukács werkt deze gedachte uit en stelt dat klassenbewustzijn in wezen ook een historisch bewustzijn een inzicht in de totaliteit van het historisch proces en de eigen positie hierin - is, wat proletariaat van een onwetend object van de geschiedenis tot een identiek 'subject-object' maakt, wiens 'praxis' de werkelijkheid op haar beurt weer kan veranderen. ${ }^{30}$

Hiermee legt Lukács een dialectiek vast die we in Mannheims generatieconcept terug zien keren. In deze dialectiek komt een historisch gesitueerde eenheid (klasse of generatie) door externe beïnvloeding vanuit de historische werkelijkheid tot voortschrijdend bewustzijn van de eigen gesitueerdheid. Uit dit zelfinzicht komt men tot een bewustzijnsvol handelen, dat vervolgens de historische werkelijkheid weer beïnvloedt. Mannheim spreekt in dit geval van een onder invloed van formatieve ervaringen ontstaan bewustzijn van de generatiepositie, dat uitmondt in een generatiesamenhang, die vervolgens het historisch proces beïnvloedt door middel van generatie-eenheden. Waar klassenbewustzijn bij Lukács voor het proletariaat de mogelijkheid opent om 'werkelijk' historisch (dus revolutionair) te handelen, in plaats van slechts als onwetende speelbal van de geschiedenis te fungeren, mondt ook Mannheims generatietheorie uit in een handelingstheorie.

Generationeel handelen is bij Mannheim echter fundamenteel anders van aard dan klassengebonden handelen bij Lukács. Waar voor Lukács klassenbewustzijn kan leiden tot een proletarische revolutie en het proletariaat zo bewust in kan grijpen in het historisch proces, leidt generatiebewust handelen echter niet tot een 'opheffing' (Aufhebung) van de generatiepositie. Voor Mannheim is de generatiepositie immers geen economische positie, maar bestaat de generatieposi- tie uit objectieve biologische gegevenheden zoals de geboortedatum. Niettemin spreekt Mannheim van een 'structurele' overeenkomst tussen klassenpositie en generatiepositie. $^{31}$ Vanzelfsprekend kan generationeel handelen niet de 'objectieve' positie van de eigen levensloop 'opheffen', maar het kan het wel door betekenisvol handelen de eigen levensloop naar een hoger plan tillen - en zo indirect ook de geschiedenis bepalen.

Dat inzicht in de eigen generatiepositie hier wel degelijk relevant is maakt Mannheim duidelijk door zijn generatietheorie te koppelen aan Martin Heideggers noties van het individuele lot (Schicksal) en het collectieve lotsbestel (Geschick). ${ }^{32}$ Met Heidegger gesproken: 'in het met-elkaar-zijn in dezelfde wereld en in het openstaan voor bepaalde mogelijkheden is het lot van elk afzonderlijk al in een bepaalde richting gestuurd. [...] Het door het lot beschikte lotsbestel van het erzijn in en met zijn 'generatie' maakt het volle, eigenlijke geschieden van het erzijn uit. ${ }^{33}$

Generatiebewustzijn is inzicht in de eindigheid van het menselijk leven en het besef gezamenlijk met leeftijdsgenoten in de geschiedenis 'geworpen' te zijn. Dit besef komt, zoals bekend, tot stand in de formatieve fase, wanneer zogenaamde 'Schicksal-' of 'Polarerlebnisse' inzicht in de gesitueerdheid 'in en met' de generatie voortbrengen. Uiteindelijk is het niet de ervaring an sich die de verwezenlijking van een generatie bepaalt, maar de gemeenschappelijke blik of het gemeenschappelijke doel dat uit deze ervaring voortkomt. ${ }^{34}$ Het is de entelechie (entelecheia), het hebben (echein) van een gedeeld doel (telos), die de generatie constitueert. Op deze wijze wordt ook bij Mannheim generatiebewust handelen doelbewust handelen. Deze doelbewustheid roept echter een aantal problemen op, aangezien zij een determinisme veronderstelt en ook methodisch problematisch is voor de geschiedschrijving.

29 Zie ook: Joachim Matthes, 'Karl Mannheims "Das Problem der Generationen", neu gelesen. Generationen- Gruppe oder gesellschaftli. che Regelung von Zeitlichkeit?', Zeitschrift für Soziologie 14 (1985) 363-372; 366.

30 Georg Lukács, Geschichte und Klassenbewusstsein (Berlijn 1923) 216. Onder druk van de Derde Internationale zou Lukács zich later van deze uitspraken distantiëren.

31 Mannheim, 'Das Problem der Generationen', 525.

32 Ibidem, 542.

33 Martin Heidegger, Zijn en Tijd (Nijmegen 1998) 480 .

$34 \mathrm{Vgl}$. Pinder, Das Problem der Generation in der Kunstgeschichte Europas, 39. 
In de eerste plaats gaat Mannheim door het causale verband dat hij legt tussen formatieve ervaring en entelechisch handelen voorbij aan de mogelijkheid dat de waardeoriëntaties en het wereldbeeld van een generatie ook in de latere levensloop kunnen veranderen. M. Rainer Lepsius heeft er op gewezen dat er ook historische gebeurtenissen zijn die op alle leeftijdscohorten een vormende invloed kunnen hebben. Zelf dacht hij aan de ineenstorting van de Duitse politieke cultuur in 1945, die zo totaal was dat ook door oudere generaties de noodzaak van een ander politiek bestel erkend moest worden. De democratische Bondsrepubliek Duitsland zou uiteindelijk opgericht worden door de Keizerrijkgeneratie met Adenauer als boegbeeld, om gedragen te worden door de nationaal-socialistische generatie. Hoewel de rol van voormalige nazi's in het democratisch bestel van de BRD nooit onomstreden is geweest, wijst de mate van participatie in, alsook het succes van het democratisch bestel erop dat de invloed van de ineenstorting van het Derde Rijk een generatieoverstijgende breukervaring is geweest. Democratie bleek ook op latere leeftijd nog aan te leren. ${ }^{35}$ Zeker binnen de politieke geschiedenis zijn er voorbeelden te over van individuen en 'generatieeenheden' die op latere leeftijd een radicale politieke ommezwaai maakten doordat nieuwe maatschappelijke omstandigheden hen nieuwe vragen deden stellen die vanuit hun bestaande denkstructuur niet beantwoord konden worden. Georg Lukács zelf is hier met zijn spontane bekering tot het marxisme een treffend voorbeeld van.

Ten tweede roept de koppeling tussen ervaring, bewustzijn en handelen ook vragen op over de ontologische status van de generatie. Door de generatie als handelingseenheid op te vatten neemt Mannheim een historisch-realistische positie in, waarbij het generatiebewustzijn niet bestaat uit een bepaalde identiteitsopvatting, uit ervaringskennis of toekomstverwachtingen (deze worden gesi-

35 M. Rainer Lepsius, 'Kritische Anmerkungen zur Gener ationenforschung', in Ulrike Jur eit en Michael Wildt eds., Generationen: zur Relevanz eines wissenschaf tlichen Grundbegriffs (Hamburg 2005) 45-52; 49.

36 Zie: Andreas Schulz en Gundula Grebner, 'Generation und Geschichte. Zur Renaissance eines umstrittenen Forschungskonzepts', in: idem eds., Generationswechsel und historischer Wande! (München 2003) 1-23:5.

37 Ibidem, 3.

38 Karl Popper, De armoede van het historicisme (Utrecht 1967).

39 Ibidem, 121-122. tueerd in de entelechie), maar bestaat uit een inzicht in de objectief-historische gesitueerdheid van de generatiepositie. Op deze wijze leidt het historisch materialisme indirect tot een historisch-realistische generatieopvatting, waarbij generaties als objectief existerende collectieve entiteiten in het historisch proces worden opgevat. Vanuit dit perspectief hoeft het dan ook niet te verbazen dat Mannheims generatietheorie voornamelijk gelezen en gebruikt is als een theorie van sociale ontwikkeling. ${ }^{36}$

Ten derde is Mannheims generatietheorie in methodisch opzicht historisch reductionistisch. In feite is de teleologische component in zijn theorie overheersend. Dit leidt bij historici tot een retrospectieve tunnelvisie, waarbij latere handelingen wel terug herleid moeten worden op de formatieve ervaring, aangezien de term 'generatie' zonder formatieve ervaring een leeg omhulsel wordt. We hebben te maken met een cirkelredenering aangezien sociaal-culturele uitingen en handelingen generationeel verklaard worden, terwijl de generatie al conceptueel voorondersteld wordt. Overige verklarende variabelen worden vervolgens ook in het generationeel stramien geplaatst. De cirkelredenering is compleet wanneer 'machtswisselingen in categorieën van generatiewisselingen (of omgekeerd) geduid worden en klassenantagonismen als generatieconflicten geherinterpreteerd worden. ${ }^{37}$

Hoewel Mannheim zich sterk historistisch opstelt door de specifieke historische context van de formatieve periode te benadrukken, maakt het terugvallen op het historisch materialisme dit historisme tot wat Karl Popper historicisme noemde. ${ }^{38} \mathrm{Het}$ historicisme is een sociaalwetenschappelijk historisme dat zich rekenschap geeft van de veranderlijkheid en onwetmatigheid van de geschiedenis, maar desondanks de ogen sluit voor de contingentie van deze veranderlijkheid zelf. 'De historicist richt voortdurend verwijten aan het adres van degenen, die zich geen verandering in hun beperkte wereldje kunnen voorstellen, maar het schijnt, dat het de historicist zelf aan verbeeldingskracht ontbreekt, want hij kan zich niet voorstellen, dat er een verandering zou kunnen zijn in de voorwaarden waaronder verandering plaatsvindt. ${ }^{39}$ Op gelijke wijze is Mannheims generatietheorie meer dan enkel een analytisch 
model: een poging de generatie methodisch te determineren als één van de belangrijkste 'fundamentele factoren bij de totstandkoming van de historische dynamiek'. ${ }^{40}$

\section{Van generationele handeling naar genera- tionele herinnering}

Mannheims generatietheorie staat of valt met de handelingsclausule, omdat dit het mogelijk maakt historische ontwikkelingen terug te koppelen aan afzonderlijke generaties. Wanneer we de vraag stellen hoe het generatiebegrip theoretisch ingevuld dient te worden om als zinvolle historische categorie opgeld te blijven doen, moet het duidelijk zijn dat we de pretentie om vanuit een generatiedynamiek het historisch proces zelf oorzakelijk te verklaren moeten laten varen.

Onvrede met de conceptuele invulling van het generatiebegrip heeft in Duitsland - waar het historisch generatiedenken de laatste jaren een opmerkelijke vlucht heeft genomen - al geleid tot de opvatting dat generaties het best geïnterpreteerd kunnen worden als collectieve 'zelfduidingscategorie'. In navolging van Reinhart Kosellecks waarneming dat de temporele horizon in de samenleving bij uitstek geconstitueerd wordt door generatiewisseling en generatiegroepen, worden generationele zelfduidingen gedeconstrueerd en wordt de generatie gedacht als een 'zeitlicher Ordnungsbegriff. ${ }^{41}$ Generaties vormen dan een bemiddelende categorie tussen ervaring en temporaliteit, waarbij de kern ligt in een 'kollektive Geschichtlichkeit'.42 Deze collectieve historiciteit ontstaat als gevolg van de dialectiek tussen ervaring en toekomstverwachting.

Met deze opmerkingen sluiten Koselleck en zijn navolgers aan bij het door Mannheim reeds uitgewerkte belang van de ervaring van de versnelling van maatschappelijke verandering. $\mathrm{Z}_{\mathrm{ij}}$ zien echter de generatievorming niet als een verwezenlijking van reeds in het historisch proces besloten liggende generaties-an-sich, maar als het product van de communicatieve uitwisseling van gelijktijdig in de levensloop opgedane ervaringen. ${ }^{43}$ Hiermee zijn generaties geen in de sociale werkelijkheid aanwezige reële entiteiten, maar sociale constructies, of beter: identiteitsconstructies. Generationaliteit omvat nu een geheel aan leeftijdsspecifieke 'inhoudelijke toeschrijvin- gen', waarmee mensen zichzelf en hun eigen ervaringen in de tijd positioneren. ${ }^{44}$

Deze 'inhoudelijke toeschrijvingen' bestaan voornamelijk uit 'zelfduidingen' die gedeelde ervaringen verwoorden, maar generationaliteit kan ook van 'buiten af' toegeschreven worden door leden van andere generaties..$^{45}$ In de wisselwerking tussen zelfduiding en externe toedichting kan een generatieretoriek ontstaan die tot op zekere hoogte zelfvervullend kan werken. Hans Righart geeft hier een treffend voorbeeld van wanneer hij de invloed van de popmuziek op de generatievorming in de jaren zestig beschrijft. ${ }^{46}$ De ontstane 'generatie-samenhang' van de protestgeneratie is volgens Righart voor een belangrijk deel aan de generatie- en revolteretoriek uit de veelbeluisterde popsongs te danken. De popsong is geen uiting van een reeds sluimerende generatie-entelechie, zoals Mannheim zou beweren, maar een samenspel van commerciële belangen en de verwoording van leeftijdsspecifieke ervaringen. Met popsongs konden jongeren zich identificeren en zich de generationaliteit eigen maken.

In feite heeft het spreken van, over of uit naam van een generatie op deze manier een zelfvervullende werking. Aleida Assmann spreekt dan ook van het generatiediscours als een 'performatief discours' dat de thema's die het beschrijft in de rol van medium van een collectieve generatiebiografie tegelijkertijd zelf voortbrengt. ${ }^{47}$ De consequentie van deze conceptualisering is dat het onderscheid tussen generationaliteit in de historische praxis en de generatie als analytisch concept dichter bij elkaar komen te liggen, wat ook de wis-

40 Mannheim, 'Das Problem der Generationen', 565

41 Reinhart Koselleck, 'Historik und Hermeneutik', in: idem, Zeitschichten. Studien zur Historik (Frankfurt am Main 2000) 97-118; 107; Ulrike Jureit en Michael Wildt, 'Generationen', In: idem eds., Generationen. Zur Relevanz eines wissenschaftlichen Grundbegriffs (Hamburg 2005) 8-26; 10.

42 Sabiene Autsch, Erinnerung-Biographie - Fotografie. Formen der Ästhetisierung einer jugendbewegten Generation (Potsdam 2000) 23. Zie ook: Burkhard Liebsch, 'Wahrnehmende Geschichtlichkeit, kollektives Gedächtnis und histor isches Wissen', in: Krist in Platt en Mihran Dabag eds., Generation und Gedächtnis. Erinnerungen und kollektive Identitäten (Opladen 1995) 255-283.

43 Zie voor de discursieve constructie van generationaliteit: Robbert-Jan Adriaansen, Tussen ervaring en herinnering, 75-105.

44 Ute Daniel, Kompendium Kulturgeschichte. Theorien, Praxis, Schlüsselwörter (Frankfurt am Main 2001) 331.

45 Jürgen Reulecke, 'Generation/Generationality, Generativity, and Memory', in: Astrid Erll en Ansgar Nünning eds., Media and Cultural Memory (Berlijn/New York 2008) 119-125; 119.

46 Zie: Hans Righart, 'De muzikale formattering van een generatie. Popmuziek en de jaren zestig', Sociologische Gids 46 (1999) 391-406; 394.

47 Assmann, Geschichte im Gedächtnis, 53. 


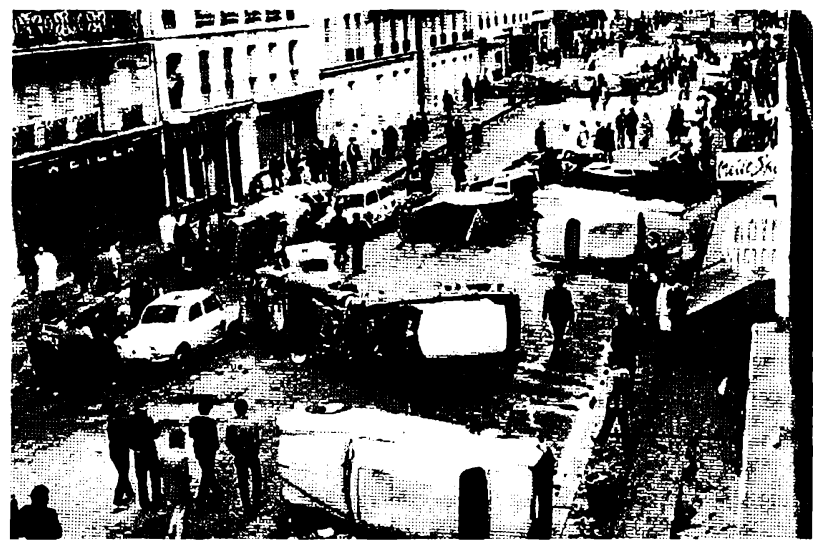

Barricaden in Parijs, 1968.

Bron: wikipedia.org selwerking tussen zelfconceptualisering en literaire of wetenschappelijke generatietyperingen analyseerbaar maakt.

Vanuit deze positie is het een kleine stap naar de typering van generaties als imagined communities. ${ }^{48} \mathrm{Hierbij}$ worden generaties, in verwijzing naar Benedict Andersons bekende definitie van de natie, opgevat als ingebeelde gemeenschappen van leeftijdsgenoten die hun identiteit baseren op een gedeeld verhaal van een gezamenlijk verleden. $\mathrm{Nu}$ zijn bij elke imagined community gemeenschappelijke ervaring en vergelijkbare levensomstandigheden ontstaansvoorwaarden, maar wat de inbeelding van generationaliteit betreft merkt Mark Roseman op dat in de door hem onderzochte casus Duitsland ook overleverde mythen en denkkaders bijdroegen aan de verbeelding van een generatie. Roseman doelt hier op een 'jeugdmythe' die al sinds de dagen van Sturm und Drang als generatieover-

Mark Roseman, 'Generationen als "Imagined Communities". Mythen, generationelle Identitäten und Generationenkonflikte in Deutschland vom 18. Bis zum 20. Jahrhundert', in: Ulrike Jureit en Michael Wildt eds., Generationen. Zur Relevanz eines wissenschaftlichen Grundbegriffs (Hamburg 2005) 180-199. Zie ook: J.J.A. van Doorn, Gevangen in de tijd Over generaties en hun geschiedenis (Amsterdam 2002) 201. ontwikkeling van het generatiebegrip onvoldoende koppelt aan de generatiegeschiedenis zelf. Wat hij eigenlijk doet is de Duitse generatieopvatting, met de autonome rol die zij de jeugd toedicht, terugprojecteren op de Franse geschiedenis om de analogie tussen ' 89 en ' 68 in stand te houden. Dit, terwijl het generatiebeg tip in Frankrijk tot diep in de twintigste eeuw niet eens gekoppeld was aan de jeugd, maar nog altijd aan de werkzame periode van de volwassenheid. Zie voor dit laatste: Wohl, The Generation of 1914.73.

stijgend leidmotief in de Duitse moderne geschiedenis diverse generaties beïnloed heef $t$. Paradoxaal genoeg was het zo een 'typisch Duitse culturele continuiteit, die immer weer generationele breuken en conflicten opriep of haar explosieve kracht verleende'. ${ }^{49}$

$\mathrm{Nu}$ valt de typische 'Duitsheid' van de generatie als sociaal denkraam enigszins te relativeren. Robert Wohl heef $t$ in zijn studie The Generation of $1914 \mathrm{al}$ aangetoond dat het generatiedenken in het Interbellum door heel Europa tot bloei kwam als burgerlijk substituut voor marxistische klassenanalyse..$^{50}$ Bovendien laat Pierre Nora zien hoe juist in Frankrijk een jeugdmythe ontstond die doorwerkte in de generatieperceptie van tijdgenoten. Ook Nora koppelt de geboorte van de moderne generatie aan de versnelling van de geschiedenis, maar tevens aan de opkomst van de democratie, waarmee hij uitkomt bij de Franse Revolutie als aanvangspunt van het moderne generatiedenken. ${ }^{51}$ Leidmotieven, zoals de barricades, keren bij vrijwel alle belangrijke generaties in de Franse geschiedenis - 1789 - 1848 - 1968 - terug, hetgeen Nora laat concluderen dat niet zozeer de barricade, als wel de generatie zelf als lieu de mémoire in het Franse nationale geheugen kan gelden. ${ }^{52}$

Los van de vraag waar in Europa het moderne generatiedenken zijn oorsprong heef $t$, is de constatering dat generaties geen autonome historische handelingseenheden in de geschiedenis zijn, maar ex-post constructies zijn die leeftijdsspecifieke ervaring sociaal mediëren, een belangrijke stap om voorbij Mannheims generatieconcept te ko- 
men. Omdat ex-post constructie in wezen een herinneringsact is, is het in mijn ogen verstandiger te spreken van generaties als herinneringseenheid in plaats van handelingseenheid. In het adjectief 'herinnering' zit het verbeelde karakter van de generatie al besloten. Op deze manier is het mogelijk de generatie te handhaven als een concept dat die meer omvat dan een identiteitstoewijzing van buitenaf door tijdgenoten of historici.

Het analyseren van generaties als herinneringseenheden biedt bovendien een oplossing voor een ander vraagstuk dat binnen de sociologische generatietheorie nooit bevredigend is beantwoord: de vraag naar de omvang van de generatie in zowel ruimtelijke als temporele zin. Voor Mannheim wordt de generatiepositie ruimtelijk bepaald door de grenzen van de historische leefgemeenschap waarin een generatie opgroeide. Het behoeft - om Mannheims voorbeeld aan te houden - weinig argumentatie dat de wereld van Pruisische jongeren rond 1800 dusdanig verschilde van die van Chinese leeftijdsgenoten dat een gedeelde generatiesamenhang nooit tot stand zou kunnen komen. De ondergrens van de generatieomvang wordt bepaald door de grootte van de groep leeftijdsgenoten die potentieel in de juiste positie verkeerde om bepaalde ervaringen te ondergaan - wat wil zeggen dat boerenkinderen in de afgelegen streken van Pruisen te ver van de burgerlijke cultuur verwijderd waren om überhaupt te delen in de ervaringen die ten grondslag lagen aan de Romantische generatie..$^{53}$ Desalniettemin blijft de kloof tussen de kleine groep kunstenaars van de Sturm und Drang-generatie en de miljoenen van de frontgeneratie uit de Eerste Wereldoorlog praktisch onoverbrugbaar. In de praktijk neemt men dan doorgaans ook de natiestaat als referentiekader voor de omvang van een generatie, los van Mannheims aanbevelingen.

Ook de temporele begrenzing van de generatie is bij Mannheim niet onproblematisch. Mannheim geeft aan dat de ontvankelijkheid voor formatieve ervaringen tussen het vijftiende en vijfentwintigste levensjaar het grootst is - iets wat nog altijd wordt onderschreven door de psychologie. Toch maakt hij een uitzondering voor avant-gardistische leden van een oudere generatie die in veel gevallen als inspiratoren of leiders van een specifieke generatie gelden - 'precies zo- als het mogelijk is dat de voorlopers van een klasse-ideologie nog overwegend tot een andere klasse behoren.'54

Welnu, als we de generatie als herinneringseenheid opvatten worden de grenzen van de generatie flexibeler, maar helderder. Of men tot een generatie behoort hangt nu niet af van het geboortecohort of van het al dan niet persoonlijk ondergaan van bepaalde formatieve ervaringen. Nee, het behoren tot een generatie hangt samen met de mate waarin men de eigen autobiografische herinnering synchroniseert met de generationele herinnering. Een generatie ontstaat nog altijd in de formatieve periode, wanneer leeftijdsgenoten gebeurtenissen duiden door ervaringsuitwisseling en op deze wijze een gemeenschappelijke herinnering creëren over deze gebeurtenissen. Dit gedeelde verhaal over een gezamenlijk verleden verschaft een generatie een narratieve identiteit die noodzakelijkerwijs een plot kent dat ook op de toekomst georiënteerd is. Waar de generatie begint en eindigt hangt noch samen met de grootte van de groep mensen die daadwerkelijk dit plot probeert te verwezenlijken, noch met de grootte van de groep die persoonlijk de formatieve ervaring heeft ondergaan. Het hangt daarentegen simpelweg samen met de vraag of men het eigen levensverhaal wel of niet terug wil herkennen in de generationele herinnering. Of men nu wel of niet aanwezig was in Parijs in mei 1968, of men toen dertien of drieëntwintig jaar oud was, of men toen überhaupt de Franse nationaliteit bezat doet minder terzake dan de vraag of men zichzelf herkent in de generationele herinnering. Een Bretonse boerenzoon die in mei 1968 slechts twaalf jaar oud was kan nog op dertigjarige leeftijd zijn eigen problemen met het ouderlijk gezag gaan zien in het licht van de revolteretoriek van de jaren zestig en kan zo zijn eigen levensverhaal retrospectief verknopen met de collectieve autobiografie van de protestgeneratie.

De grenzen van de generatie liggen dus daar waar de zelfidentificatie met de generationele herinnering ophoudt. Tegelijkertijd betekent dit dat ook de 'omvang' van de formatieve ervaring zelf niet relevant is voor de mate waarin een generatie gevormd wordt.

53 Mannheim, 'Das Problem der Generationen', 542-543.

54 Ibidem, 549. 
Immers, what makes them communal is not their scale but the reference to the we..$^{5}$ Overigens, wanneer een historicus in de bestudering van een generatie de generationele herinnering deconstrueert, is de exacte omvang van een generatie sowieso van minder belang dan wanneer men de praktische werking' van een generatie in het historisch proces volgens de principes van Mannheim wil vaststellen.

\section{De generatie als metahistorische categorie}

Door de generatie als herinneringseenheid op te vatten laten we niet alleen Mannheims historisch realisme achter ons, maar ook het gevaar van reductionisme. Deconstructie van een generationeel discours kan de gemeenplaatsen van de generatie blootleggen zonder dat hier een vooraf toegeschreven 'generationeel handelen' aan te pas komt. Dit betekent wellicht dat de verklarende waarde van de generatie als scheppende kracht in het historisch proces sterk gerelativeerd wordt, maar het neemt niet weg dat de generatie één van de fundamentele elementen in de totstandkoming van de 'historische dynamiek' blijft - zij het niet in historisch-materialistische, maar in metahistorische zin.

Een van de sterkste punten uit Mannheims generatietheorie is namelijk het verband dat hij legt tussen generationaliteit en historisch bewustzijn. Een generatie-entelechie kan volgens Mannheim pas ontstaan wanneer het tempo van sociale verandering zo hoog ligt, dat de aanpassing van traditionele waarden achterblijft en de jeugd een eigen weg gaat zoeken in reactie op de nieuwe maatschappelijke omstandigheden. ${ }^{56}$ Historische generaties bestaan dus bij gratie van de 'onvanzelfsprekendheid' van kennisoverdracht in een aan verandering onderhevige moderne wereld. 'Aangeleerde herinnering' blijft - aldus Mannheim - minder snel

55 David Carr, Time, narrative and history (Bloomington 1986) 167.

56 Mannheim, 'Das Problem der Generationen', 551-555.

57 Ibidem, 534.

58 Zie voor een inleiding op deze thematiek: Douwe Draaisma, 'Reminiscenties', in: idem, Waarom het leven snellergaatalsje ouder wordt (Groningen 2001) 176-204. Het reminiscentie-effect werd overigens in 1977 ontdekt: H. C. Franklin en D.H. Holding, 'Personal memories at different ages', Quarterly Journal of Experimental Psychology 29 (1977) 527.532.

59 S.M.J. Janssen, A.G. Chessa en J.M.J. Murre, 'The reminiscence bump in autobiographical memory: Effects of age, gender, education, and culture', Memory 13 (2005) 658-668; 666. hangen dan 'zelf verworven herinnering. .7 Aangezien Mannheim de generatie interpreteert als de sociale sfeer bij uitstek waar zelf verworven ervaringsruimte omgezet wordt in een entelechische verwachtingshorizon, sluit hij hier aan bij Kosellecks opmerkingen over de constitutieve rol van generatiedynamiek voor temporele horizonten in een samenleving. Zoals bekend problematiseert Mannheim het generatieconcept door te stellen dat de generatie vooraf gaat aan de herinnering, maar dit neemt niet weg dat de kern van zijn betoog, namelijk het 'formatieve' karakter van de adolescentie bij individuele identiteitsvorming ook voor de herinnerende generatie opgaat.

Binnen de cognitieve psychologie keert de adolescentie terug als de belangrijkste levensfase met betrekking tot autobiografische, zelf verworven, herinneringen aan de eigen levensgeschiedenis. Naarmate men ouder wordt, herinnert men verhoudingsgewijs meer ervaringen die men tussen (ruwweg) het vijf tiende en vijfentwintigste levensjaar op heeft gedaan, dan ervaringen uit de rest van de levensloop. Verwijzend naar de 'hobbel' die bij de periode van adolescentie en jongvolwassenheid ontstaat wanneer men in een grafiek het aantal opgehaalde herinneringen afzet tegen de leeftijd van de ondervraagde, wordt dit fenomeen wel de 'reminiscence-bump' en in het Nederlands het 'reminiscentie-effect' genoemd..$^{58} \mathrm{Het}$ reminiscentie-effect wordt zichtbaar wanneer men proefpersonen van ongeveer vijfendertig jaar en ouder herinneringen op laat halen aan de hand van een voorgeprogrammeerde lijst steekwoorden, of uit vrije associatie. Bij proefpersonen jonger dan vijfendertig wordt het reminiscentie-effect vertroebeld door het 'recency effect' van herinneringen aan recente gebeurtenissen. ${ }^{59}$

$\mathrm{Nu}$ zijn persoonlijke herinneringen voor de generatie minder relevant dan herinneringen aan de publieke gebeurtenissen die Mannheim als formatieve 'Schicksalerlebnisse' opvatte. Echter, ook publieke gebeurtenissen kennen een reminiscentie-effect. In een belangrijk - maar in het historisch generatiediscours grotendeels onopgemerkt gebleven - onderzoek naar het reminiscentie-effect hebben de sociologen Howard Schuman en Jacqueline Scott Mannheims these van de formatieve erva- 
ring getoetst aan de herinneringen van ruim 1400 volwassen Amerikanen..$^{60}$ In de reacties op het verzoek de belangrijkste nationale of mondiale gebeurtenissen of veranderingen van de laatste vijftig jaar te noemen, bleek zich een sterk reminiscentie-effect af te tekenen. Schuman en Scott concluderen dan ook dat de adolescentie en vroege volwassenheid de belangrijkste periodes zijn wat betreft de 'generational imprinting' van politieke herinneringen. ${ }^{61}$ Maar ook zij benadrukken dat er uit hun onderzoeksresultaten nauwelijks een verband naar voren kwam tussen de generationele herinnering en toekomstig handelen. Dit wil niet zeggen dat een dergelijk verband niet kan bestaan, maar ook deze onderzoekers bepleiten dat het verstandiger is te kijken naar de subjectieve betekenisgeving van bepaalde gebeurtenissen, dan consequenties te trekken over individueel of collectief handelen.

Schuman en Scott signaleren nog een ander empirisch probleem dat in hun onderzoek naar de spontane herinnering aan publieke gebeurtenissen onopgelost blijft. Dit is namelijk precies de verhouding tussen de levende herinnering en 'objectieve' historische kennis. Ondanks de grote overeenkomsten van de onderzoeksresultaten met het autobiografische reminiscentie-effect, bestaat er in het onderzoek van Schuman en Scott altijd nog de mogelijkheid dat men bepaalde publieke herinneringen ophaalt vanwege het toegedichte historisch belang van de betreffende gebeurtenissen - los van de generationele ervaring. ${ }^{62}$ De vraag hoe historische kennis en generationele ervaring zich tot elkaar verhouden is niet slechts een methodisch probleem bij herinneringsonderzoek, maar een van de cruciale vraagstukken van de generatietheorie.

Johan Huizinga heeft er al vroeg op gewezen dat het in de generatieproblematiek 'de innige samenhang van het historisch verstaan met het leven zelf' tot uitdrukking komt. ${ }^{63}$ Vanuit dit perspectief kunnen we bevestigen dat het zinvoller is de generatie te interpreteren als een metahistorische categorie waarin verhoudingen tot een verleden gestalte en betekenis krijgen, dan als een collectieve handelingseenheid die optreedt als een (niet eens onzichtbare) motor achter het historisch proces. De generatie is dan in die zin metahistorisch, dat zij het veld is waarin individuele bistorische ervaring communicatief geobjectiveerd wordt. ${ }^{64}$ Door ervaringsuitwisseling en de synchronisatie van individuele herinneringen met die van leeftijdsgenoten wordt een generationeel besef gevormd, terwijl hiermee tegelijkertijd de gebeurtenissen gehistoriseerd worden. De generationele herinnering vormt als interne dynamiek van de collectieve herinnering de schakel tussen gebeurtenissen en historische kennis. Om het met Paul Ricoeur uit te drukken: de afwisseling van generaties opent de mogelijkheid om subjectieve, ervaren tijd in te voegen in de objectieve, chronologische klokkentijd. ${ }^{65} \mathrm{De}$ wijze waarop de dialectiek tussen ervaring, herinnering en geschiedenis werkt wil ik illustreren aan de hand van een nadere blik op breukervaringen die zo diep inwerken op de generationele herinnering.

\section{De ogenblikkelijkheid van de generationele ervaring}

Karl Mannheim zelf blijft erg vaag over wat zijn 'formatieve ervaring' nu precies inhoudt. Hij richt zijn aandacht meer op de gevolgen van de formatieve ervaring - de generatievorming - dan op de ervaring zelf. Aangezien de generatie door Mannheim reeds ontologisch voorondersteld wordt in de geschiedenis, hoeft het voor hem ook niet uit te maken hoe de ervaring er precies uit ziet, zolang het maar ingrijpend genoeg is om generatiebewustzijn op te wekken. Ook Dilthey, van wie Mannheim de these van de formatieve ervaring overgenomen heeft, spreekt slechts over de generatie als afhankelijk van 'dezelfde grote feiten en veranderingen'. ${ }^{66}$

Ik zou willen bepleiten dat generationele ervaringen (ik zal vanaf nu niet langer van formatieve ervaringen spreken) niet zozeer vanwege de 'objectieve' omvang of impact van de gebeurtenis memorabel zijn, als wel vanwege de mate waarin een gebeurtenis als historisch

\footnotetext{
6o Howard Schuman en Jacqueline Scott, 'Generations and Collective Memories', American Sociological Review 54 (1989) 359-381.

61 Ibidem, 377 .

62 ibidem, 379

63 Huizinga, 'De taak der cultuurgeschiedenis', in: Verzamelde werken VII (Haarlem 1950) 35-94; 94.

64 Zie hiertoe ook: Nora, 'Generations', 528.

65 Paul Ricoeur, Memory, History, Forgetting (Chicago 2004) 394. Zie over Ricoeur, tijd en narrativiteit ook: Maria Grever en Harry Jansen eds., De ongrijpbare tijd. Temporaliteit en de constructie van het verleden (Hilversum 2001).

66 Dilthey, 'Über das Studium der Geschichte', 37.
} 
wordt ervaren. De generationele ervaring is daarmee een historiciteitservaring; dit is de ervaring van het 'zelf' als historisch gesitueerd, als levend in een historische wereld, die de gebeurtenis oproept bij adolescenten en jong volwassenen. De generationele ervaring is dan geen enkelvoudige ervaring van objectief waarneembare grote historische gebeurtenissen, maar een ervaring van wat Gadamer het existentiële ogenblik noemde. ${ }^{67}$ Deze ervaring is een discontinuiteitservaring, maar dan wel van een bijzonder soort. Aangezien Gadamer uitgaat van de fenomenologische verbondenheid tussen mens en verleden, is de vraag naar de wijze waarop de mens zichzelf begrijpt altijd terug te herleiden op de vraag naar zijn historiciteit (Geschichtlichkeit). Het ogenblik speelt hierin een belangrijke rol. Het verwijst niet naar een bepaald historisch belangrijk of beslissend moment, maar moet gezien worden als een 'ogenblik waarin de historiciteit van het menselijk erzijn ervaren wordt'. ${ }^{68}$

Dit maakt dat de gebeurtenissen die existentiële - en dus ook generationele - ervaringen teweeg kunnen brengen zeer divers kunnen zijn. Het kunnen zeer persoonsgebonden gebeurtenissen zijn: het weerzien van een oude vriend of het plotselinge besef dat je kind sneller opgroeit dan je wellicht zou willen. Ook veranderingen in het politieke klimaat of machtswisselingen geeft Gadamer als voorbeeld van gebeurtenissen die het inzicht kunnen oproepen dat de geschiedenis ons ingehaald heeft. Tenslotte spreekt ook Gadamer over de grote historische gebeurtenissen die historici doorgaans aanwijzen als breukmomenten in de geschiedenis. Gadamer benadrukt dat deze 'Epochenerfahrungen'

67 Hans-Georg Gadamer, 'Die Kontinuität der Geschichte und der Augenblick der Existenz', in: idem, Gesammelte Werke II (Tübingen 1993) 133-145.

68 Ibidem, 135.

69 Ibidem, 137.

70 Zie ook Veronica Vasterling over het 'volle ogenblik' bij Heidegger: Veronica Vasterling, 'De rechte lijn en de lus. Heideggers onderzoek naar de tijd en de geschiedenis van het tijdbegrip', in: Maria Grever en Harry Jansen eds., De ongrijpbare tijd. Temporaliteit en de constructie van het verleden (Hilversum 2001) 175-187.

71 Tilmann Habermas, 'Identitätsentwicklung im Jugendalter', in: Rainer K. Silber eisen en Marcus Hasselhorn eds., Entwicklungspsychologie des Jugendalters (Enzyklopädie der Psychologie: Entwicklungspsychologie Band 5) (Göttingen 2008) 364-387; 367 en 379.

72 Mario Erdheim, 'Adoleszenz und Kulturentwicklung', in: idem, Die gesellschaf tliche Produktion von Unbewu $\beta$ theit. Eine Einführung in den ethnopsychoanalytischen Proze $\beta$ (Frankfurt am Main 1984) 271-368; 297.

73 Ernst Bloch, Das Prinzip Hoffnung (Frankfurt am Main 1976) 343-368. Zie ook: Heidegger, Zijn en tijd, 423 .

74 Walter Benjamin, Das Passagen-Werk II (Frankfurt am Main 1983) 1058. niet slechts historische constructies zijn, maar ook door tijdgenoten als breuk konden worden ervaren. Het zijn gebeurtenissen die zich niet laten vergeten, die zich 'vasthouden en behouden in het bewustzijn van mensen, waarin $[\mathrm{al}]$ zoveel vergeten wordt'. ${ }^{\prime}$

Het ogenblik kan gekenschetst worden als het moment waarop de betekenis van de gebeurtenis ons ten volle raakt. Pas op dat moment opent zich de mogelijkheid om het voorafgaande als kwalitatief 'oud' te zien en ook de historiciteit van het zelf te ervaren. ${ }^{70}$ Dat generationaliteit altijd aan adolescentie gekoppeld wordt hoeft vanuit dit perspectief niet te verbazen. Het is namelijk in deze levensfase dat de mens voor het eerst leert om zichzelf historisch te verstaan en een levensverhaal ontwikkelt dat in betrekking staat tot de bredere geschiedenis. ${ }^{71}$ Dan ontstaat wat Gadamer de historiciteit van de ervaring noemt: 'de verhouding tussen herinnering en verwachting.' ${ }^{2}$ De historische ervaring van het existentiële ogenblik is dan niet dissociatief, maar associatief van aard.

Deze associatie ligt echter niet besloten in het ogenblik zelf. Op het moment van de gebeurtenis zelf bevindt de mens zich in wat Ernst Bloch het 'duister van het geleefde ogenblik' noemde, waarmee hij verwijst naar de onmogelijkheid om op het ervaringsogenblik zelf te realiseren wat men beleeft. ${ }^{73} \mathrm{Pas}$ na het ogenblik kan men de beleving (Erlebnis) objectiveren als ervaring (Erfabrung) en kan men de betekenis van de ervaring bevatten en plaatsen in relatie tot het verleden. Dit betekent inderdaad dat op het ogenblik van een subject-objectrelatie geen sprake kan zijn, dat het 'zelf' direct betrokken is op het verleden en dat er slechts een "'nog-niet-bewuste kennis" is van wat is geweest, waarvan de bevordering de structuur van het ontwaken heeft ${ }^{74}$ Pas met het ontwaken van uit de droom van het ogenblik wordt de droominhoud geobjectiveerd en wordt het verleden als historisch geïnterpreteerd. Dit betekent dat de duiding van de generationele ervaring herinneringsarbeid is en dat de generationaliteit in de uitwisseling en synchronisering van deze herinneringen besloten ligt. Het generatiebesef groeit naarmate men zich realiseert dat deze specifieke herinneringen bij andere generaties niet leven of in het licht van een reeds bestaande generatione herinnering als minder fundamenteel geïnterpreteerd worden. 


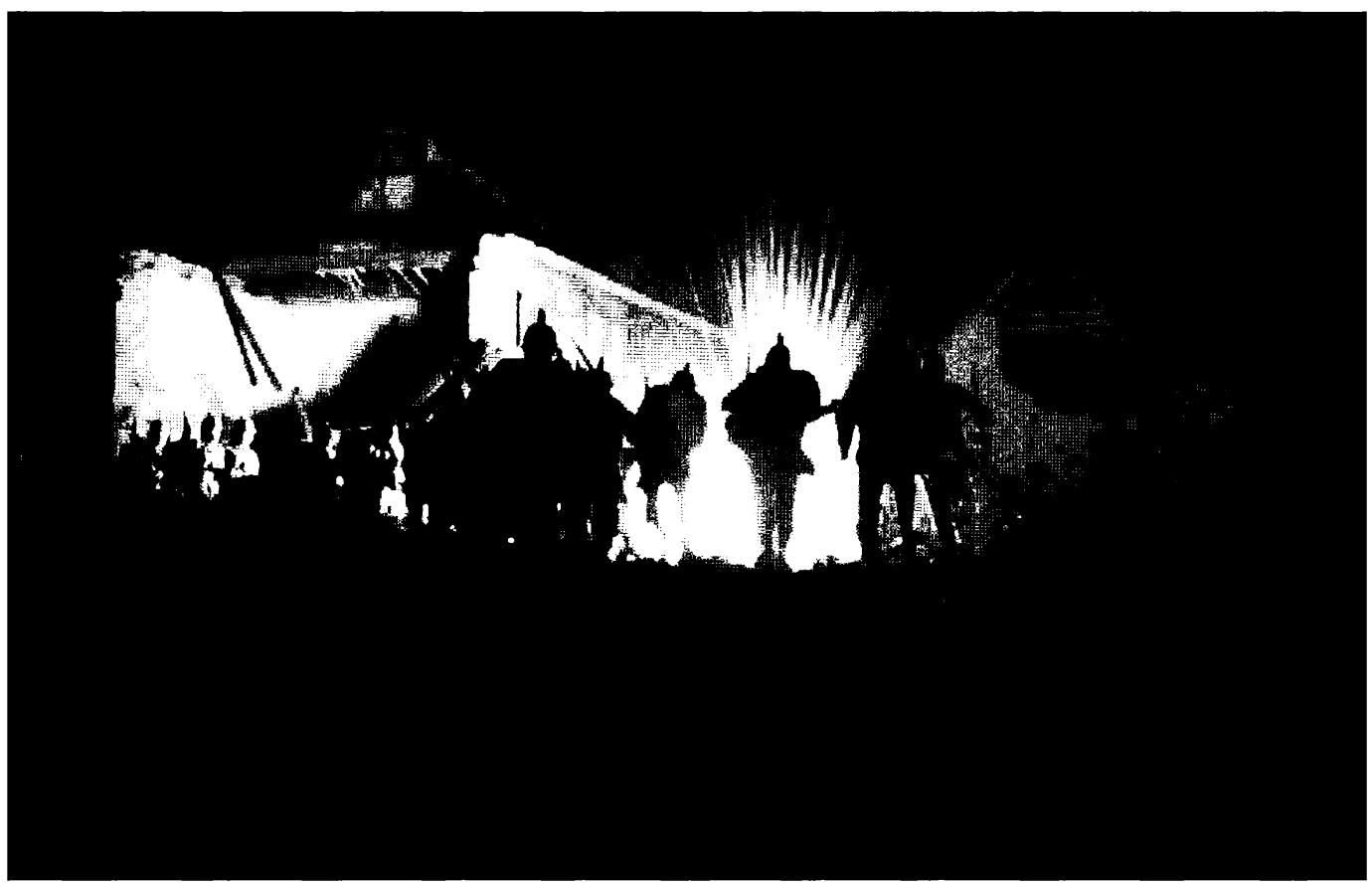

'Die erste Granate, die einschlug, traf in unser Herz.'

Bron: still uit de film All Quiet on the Western Front (1979)

Laat ik dit kort met een voorbeeld illustreren. In Erich Maria Remarque's roman Im Westen nichts Neues is de eerste granaatinslag het ogenblik dat de jonge frontsoldaten figuurlijk in het hart trof.$^{75}$ Hoe traumatisch een dergelijke ervaring op individueel vlak ook moge zijn, in generationeel opzicht was het eerder een ontnuchtering. Een ontwaken uit de mengelmoes van jeugdige drang naar avontuur, plichtsbesef en patriottisme waarmee de gymnasten zich in 1914 als oorlogsvrijwilliger hadden gemeld. De granaatinslag was het eerste moment waarop ze op zichzelf teruggeworpen werden, los van de beschermende sferen van het ouderlijk huis en de school, maar temidden van leeftijdsgenoten die in een gelijke situatie verkeerden.

In het ogenblik van de generationele ervaring kan de adolescent er niet langer onder uit de historiciteit van het 'zelf' als geworpen in de geschiedenis onder ogen te zien. Er vindt een associatie plaats met het tijdsgewricht waarop men de historiciteitservaring opdoet. Zelfs in het extreme voorbeeld van de frontervaring associëren Remarque's protagonisten zich met het ogenblik: 'we zijn afgesloten van de werkzaamheid, van het streven, van de vooruitgang. We geloven hier niet meer in; we geloven in de oorlog. ${ }^{76} \mathrm{De}$ generationele ervaring is dan geen traumatische ervaring van verlies, maar een ervaring van winst. De winst van de eigen historiciteit. Het is niet de jeugd, maar het is het geheel van de generationele ervaring en aanverwante historiciteitservaringen uit de adolescentie en jong-volwassenheid, die in de verdere levensloop het ijkpunt zullen worden van generationele herinnering en generationele identificatie. Im Westen nichts Neues is dan geen tijdsdocument dat verslag doet van het erzijn van een generatie, maar is zelf een cruciale bijdrage aan de epische verdichting van de generationele herinnering, die op haar 


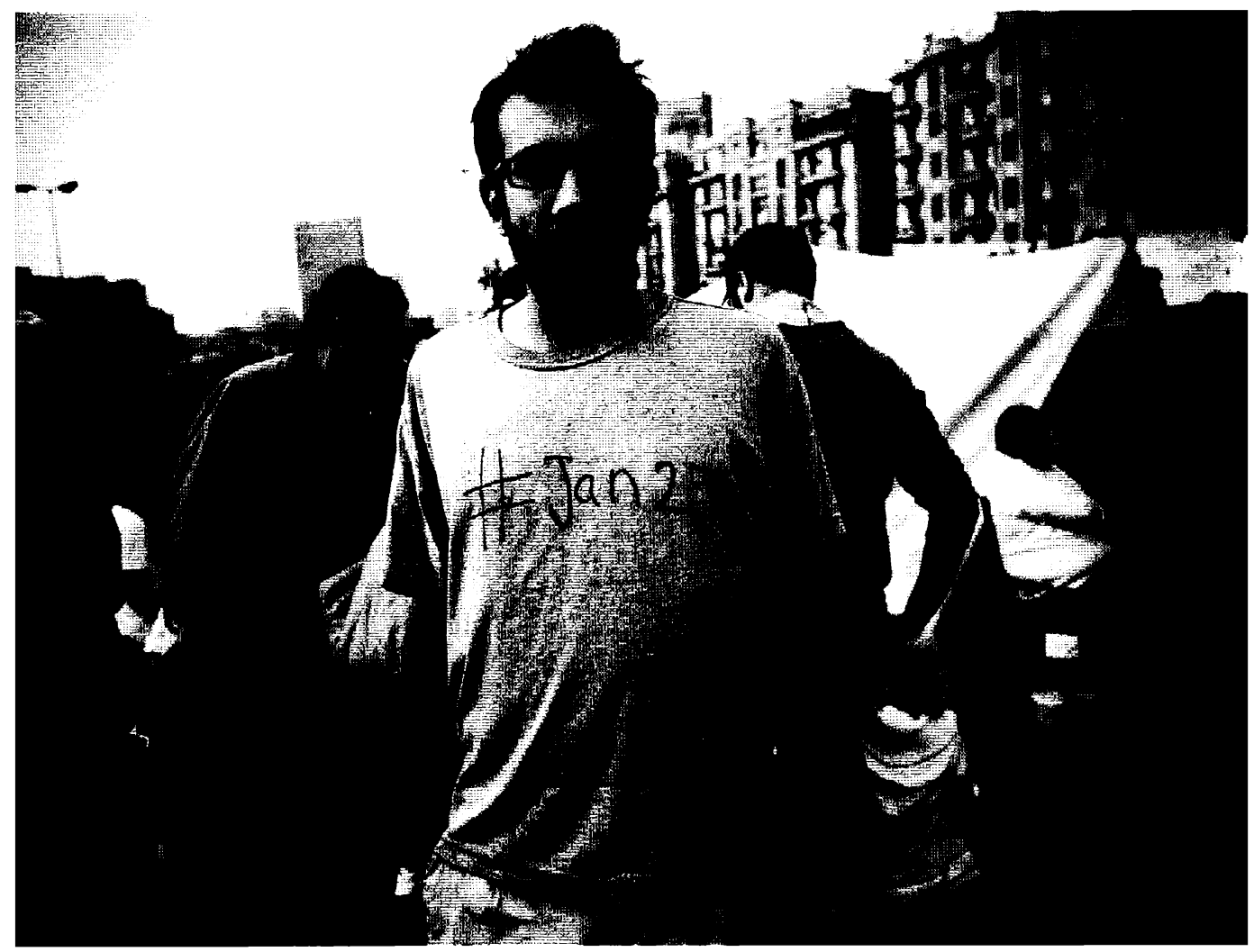

\#jan25 als generatiebeweging in Egypte, 2011.

Bron: ๑ Hossam el-Hamalawy, flickr.com

beurt juist identificatie met de generatie en synchronisatie van individuele herinneringen mogelijk maakt.

Deze generationele horizonversmelting houdt echter niet in dat de generationele ervaring als archimedisch punt aan de generationele horizon gefixeerd is. Naarmate de temporele afstand tot de generationele ervaring toeneemt en zich andere existentiële ervaringen voordoen in andere levensfasen zal men genoodzaakt zijn plotwendingen aan te brengen in de generationele herinnering. Bovendien herstelt de generationele herinnering de breuk met het verleden door middel van de historisering van de generationele
77 Gadamer, 'Die Kontinuität der Geschichte und der Augenblick der Existenz', 143. ervaring zelf. Overigens is volgens Gadamer in het ogenblik eigenlijk nooit sprake van een breukervaring, omdat de bewustwording van de historiciteit natuurlijk ook een bewustwording van de eigen historische bepaaldheid is. ${ }^{77}$ Hier staat de generatie niet alleen op het kruispunt van individu en collectief, maar ook op de grens van overlevering en nieuwe historische kennis. Een grens zo smal, dat het nauwelijks in een ogenblikgevat kan worden.

\section{Besluit}

Dat de sociologische generatietheorie van Mannheim met zijn heldere analysemodel moeilijk toepasbaar is op het contingente verleden hebben al veel historici ondervonden. Het gevaar van de 'generationele drogreden' 
ligt op de loer als men bij het schrijven van een generatiegeschiedenis blindvaart op de 'formatieve ervaring' en verdere levensloopontwikkelingen hier causaal op herleidt. ${ }^{78}$ Wanneer men in navolging van Mannheim generaties ook nog interpreteert als collectieve handelingseenheden die in grote mate bepalend zijn voor de historische dynamiek, dan maakt het achterliggende historisch-materialistische denkkader de generatietheorie tot een deterministische geschiedtheorie.

Het is zaak om niet langer het historisch proces zelf oorzakelijk te verklaren vanuit een generatiedynamiek. Dit betekent echter niet dat Mannheims generatietheorie overbodig of niet toepasbaar is geworden. De kern van zijn theorie - de voorname rol van de adolescentie en jongvolwassenheid bij de totstandkoming van generatiebesef - staat nog altijd overeind en wordt bevestigd door onderzoek naar autobiografische en collectieve herinneringen. Een herinterpretatie van de generatietheorie dient daarom in deze hoek gezocht te worden.

In het licht van de herinnering is de generatie geen historische, maar een metahistorische categorie, waarin de tijdservaring en de commemoratieve verwerking hiervan centraal staan. Generaties ontstaan wanneer de ervaring van het existentiële ogenblik wordt gedeeld in de generationele herinnering. Hierbij is het essentieel dat deze ervaringen worden opgedaan in de adolescentie, omdat men zich in deze levensfase voor het eerst bewust wordt van de eigen historiciteit. Een historiciteitsbesef is iets geheel anders dan het besef van de eigen objectieve generatiepositie dat voor Mannheim constitutief was voor de generatie. Het gaat niet uit van een uitstijgen boven het historisch proces om de koers van de geschiedenis met bewuste, entelechische, handelingsintenties in het eigen voordeel om te buigen, maar om een zingeving van de eigen geworpenheid in de geschiedenis. De generatie is een van de meest basale zingevingskaders die we kennen.

Generaties zijn dus geen handelingseenheden, maar herinneringseenheden die binnen bepaalde sociale kaders zoals verenigingen, organisaties, sociale bewegingen of naties de temporele dynamiek vormgeven. De nadruk ligt hier op vormgeven, want het idee dat generaties zelf de temporele dynamiek vormen, zoals Mannheim veronderstelt, is een speculatieve aanname die voor de historicus tot de voornoemde problemen leidt. Wanneer de historicus dit onderscheid niet maakt, bestaat het gevaar dat hij generationele mythes en zelfnarratieven eerder bekrachtigt dan ontzenuwd. In methodisch opzicht pleit ik dan ook voor een archeologie van de generationele herinnering.

Robbert-Jan Adriaansen MA is als promovendus verbonden aan het Center for Historical Culture aan de Erasmus Universiteit Rotterdam. Hij verricht momenteel onderzoek naar de omgang met het verleden binnen de Duitse jeugdbeweging. 


\title{
'Neither Right, NOR Left ?’ Debates on French fascism
}

\section{Daniel Knegt}

\begin{abstract}
Was France during the Interwar period 'immune' to fascism, or should it be considered one of the centres of fascist thinking in Europe? Was fascism in France fundamentally anti-bourgeois and 'left wing', or was it strongly related to traditional conservatism? These kinds of questions are still pivotal within the scolarly debate on French fascism, but at the same time research is also taking new directions. Through an overview of the historiographical debate on French fascism, this article analyses the development and the themes of an old discussion that is still raging strongly. Though the barriers between English and French language historians are far from gone, more mutual understanding must be possible. After all, only research taking into account political and intellectual history, programs of radical movements as well as ideas of non-conformist intellectuals, can provide meaningful answers to the big questions on French fascism.
\end{abstract}

\section{GENERATIONS, MEMORY AND HISTORICITY}

\section{Robbert-Jan Adriaansen}

Although 'generation' is a key concept in historiography, the problem of historicity has rarely been discussed within generational theory. In this article, I argue for a revision of generational thinking, which focuses on historical experience instead of political action. I start with a critical assessment of Karl Mannheims seminal essay 'the Problem of Generations' (1928). Although the core axiom of his theory - the primary importance of adolescent experiences for generational consciousness - is still valid, his historical materialist interpretation of generations is questionable as it leads to the fallacies of historicism. Alternatively, the imagined character of the generation is emphasized and a reinterpretation of the generational experience as an experience of historicity is proposed. Consequently, the generation is no longer understood as an agent of sociohistorical change, but as a meta-historical category in which the individual's placement in history is both cognitively understood and socially mediated.

\section{Contramine: the Grey Perspective}

The third issue of the Tijdschrift voor Geschiedenis in 2010 contained an article by Martijn Eickhoff, Barabara Henkes, and Frank van Vree entitled: 'The Temptation of a Grey Perspective. Moral Values and the Writing of History'. In this article the authors reflected on the moral values of historical-writing, discussing three historiographical themes: the Dutch colonial past, the Second World War and the NIOD. report about Srebrenica. In examining the value of historical qualifications in terms of 'good', 'bad' and 'grey', they attributed a specific moral meaning to the grey accommodation-paradigm.

It is not surprising that their discussion of the historiography of the Second World War combined with their critical assessment of the grey perspective has provoked a reaction. In 'Absurdities about a book' Chris van der Heijden responded to what he considered to be an attack on his views. The three authors of the previously-mentioned article reply to this criticism. 